\title{
Does Distribution in Public Spending on Education Matter for Cameroon's Economic Growth
}

\author{
Romuald Foueka ${ }^{1 *}$ \\ Faculty of Education, University of Ngaoundere, PO Box 454, Ngaoundere, Cameroon
}

\begin{abstract}
:
This paper analyzes the distribution's effects of public spending on education (PSE) on economic growth in Cameroon. Government spend around 3.5 and 5 times respectively for children of secondary and higher education than primary level and the opportunity cost represents 5.5\% of GDP in Cameroon at 2010. PSE are progressive at the level of primary education and regressive in the upper levels. We appreciated the effect of this distribution on growth over the period 1982-2012. Our results reveal that the still high level of inequality in public spending on education leads to negative rates of growth. While the primary school level acts negatively on growth, we find that PSE at high level have positive effects. The combination of various effects of PSE weakens the accumulation of human capital essential in promoting growth.
\end{abstract}

Keywords: Public spending on education (PSE), Education costs, Redistributive effect, Growth.

Jel Classification: D63, H52, I22, O55.

DOI: $10.7176 / \mathrm{JEP} / 12-2-04$

Publication date: January $31^{\text {st }} 2021$

\section{Introduction}

Ensure social justice by the improvement of a better distribution of human capital. This is the main argument behind public intervention in the education sector in most developing countries (DC). This argument gives a theoretical anchorage to rising public expenditure on education (PSE) in these countries. However, an increase of PSE unequally distributed between different education levels may have adverse effects on the economy: small reduction of poverty, strengthening inequalities and economic rents.

A recent economic literature has focused on the distribution of human capital investment to support sustainable economic growth [Driskill and al (2007), Blankenau and Abington (2013), Su (2004), Arcalean and Schiopu (2008), Ben Mimoun (2007)...]. This literature demonstrates explicitly that excessive emphasis placed by several countries in Latin America or sub-Saharan Africa on higher education to the detriment of primary and secondary education could strengthen the adverse effects of high inequality and the financial constraint on investment in post-primary teaching in these countries. Such a political choice and helps to explain why these countries have weakest enrollment rates in the graduate level as OECD countries, or even South-East Asia where the organization of education has made on much less elitist principles.

New growth theories teach that especially innovation and technological adaptation that pull productivity in economies. Or they depend heavily on the ability of education systems to develop a skilled workforce. For the more advanced countries, meaning close to the "technological frontier" (whose ultimate representative is the United States), this is to focus on higher education, research and development, etc. Countries far from the technological frontier (mostly sub-Saharan Africa) are preferred for their imitation and catching up, then concentrating efforts and financial resources on primary and secondary education (Aghion and Cohen, 2004) ${ }^{1}$. The importance of such statement is related to the hierarchical nature of any education system.

The review of UNESCO statistics on education spending reveals drastic differences between countries in terms of education funding policies. These differences lie not only in the levels of public budgets for education, but especially in the patterns of allocation of these budgets between enrollment cycles. As an illustration and according to statistics available in 2002, when the average in OECD countries, $39 \%$ of public expenditure allocated to primary education which has $42 \%$ of the school population, all developing countries allocate on average $40 \%$ of their education budgets to this cycle with over $63 \%$ of the educated workforce. Similarly, when the population in the high education in the OECD countries representing $20 \%$ of all students receives on average $19 \%$ of PSE, more than $20 \%$ of education budgets are intended in developing countries (DC) in funding this cycle whose population does not exceed $7 \%$ of all students. So doing, the ratio of public spending per pupil per year between higher and primary education averages around 2 in the OECD countries, while it exceeds 10 widely in many DC.

In Cameroon, this allocation is as follows. Primary education with $70 \%$ of enrollments in 2010 received only $40 \%$ of spending on education against $50 \%$ for secondary that has $26 \%$ of enrollments and $10 \%$ for higher education has $4 \%$ of enrollments (trend observed since 2005). In parallel and in view of enormous natural and

\footnotetext{
${ }^{1}$ An important micro-econometric literature born of the work of Mincer (1974), synthesized by Psacharopoulos (1994) and updated by Psacharopoulos and Patrinos (2004) focuses on educational returns. These show that private and social returns to education differ from one cycle to another school with a tendency to superiority marginal returns related to primary education.
} 
human potential that abounds Cameroon, the country has recorded low growth rates during the PRSP implementation period (2003-2007) of the order of 4 to $5 \%$. This slow growth has continued since the implementation of GESP with low observed rates of around 3.5\%, 4.2\%, 5\% and 4.6\% respectively in 2010, 2011, 2012 and 2013. Can we not think that these poor economics performances are linked to the unequal distribution of PSE between the different educational levels that feed the sectors of the economy?

To answer this question we set ourselves the goal in this article to analyze the effects of the distribution of human capital investment on economic growth in Cameroon. This objective is divided into two sub-objectives: (i) analyze the educational costs and efficiency of PSE; (ii) assess the effect of the distribution of PSE on economic growth.

The rest of the article is organized as follows: section two presents the elements of literature on the economic effects of the distribution of PSE. In section three we propose an analysis of the different costs of education and efficiency of PSE in Cameroon. The results of estimating the growth equation with disaggregated data of PSE are presented and analyzed in section five. Finally, section six is devoted to the conclusion of the study.

\section{ECONOMIC EFFECTS OF THE DISTRIBUTION OF PUBLIC SPENDING OF EDUCATION: Literature review}

Mankiw, Romer and Weil (1990) find a positive and significant effect of the level of human capital (and not in the growth rate of the latter), measured by the average number of years of education among the workforce early the reporting period, on the average growth rate of GDP per capita. This result is confirmed by Krueger and Lindahl (2001) who used better databases and highlighted a significant role in the growth of both the accumulation and the initial level of human capital in a panel of 110 countries observed between 1960 and 1990. Aghion and Cohen (2004), for their part and with more recent data also demonstrate the impact on growth as well as an increase in the number of years of education (cumulative effect) that the number of years of studies itself (level effect). Also relevant they in terms of contribution to understanding the role of education in economic growth in the long term, different approaches have inadequacies ${ }^{1}$. They often put on the same level all the years of education (primary, secondary or higher) and imply that all types of education regardless of their nature (literary, professional or scientific etc.) lead to the same so as to improve the overall productivity. But logic suggests that a differentiated education has an impact on growth year whatever the level of education considered. Three orientations of this human capital disaggregation logic are found in the empirical literature: the first analyzes the effect of human capital at each level of growth studies while the second focuses on PSE of each grade level. The third takes into account simultaneously the two first orientations.

In order to generate an optimal diagram of PSE allocation between the different levels of education, it is best to study the impact of human capital trained in various school cycles and not to take into account only the average number of years of study or enrollment rates as a proxy of the stock or the accumulation of human capital available to an economy. This new hypothesis was discussed and tested in three approaches.

Mingat and Tan (1998) taking into account that the productivity of human capital levels of education may vary in different contexts, arrive at show that the impact of education differs significantly depending on the initial level of economic development on the one hand and the educational level considered other. They demonstrate the gradual shift of the role of educational levels with the level of economic development. The findings of their study emphasize the importance of primary education in the least developed countries, the secondary school in intermediate countries and the higher in economically advanced countries. [Glomm and Ravikumar (2001), Basdevant (1999), Gemmel (1995) ...].

Driskill and al (2002 and 2007) admit, meanwhile, that basic education is transformed to higher levels in a sequential process that generates a hierarchical structure that is separate from the physical capital. Their empirical implications validate the thesis of inventory change and illustrate how the accounting of the hierarchical human capital contributes to the literature of growth. This result is also obtained by Fuente and Domenech (2006) which take account human capital through education. They go even further, demonstrating that the consideration of the hierarchical structure can explain about $80 \%$ of the variation of the country between factors of productivity growth.

The results of work based on internal returns of the different educational levels, has like those of Psacharopoulos and Patrinos (1994) have inspired funding policies or allocation of financial resources in the education systems despite the quality not robust which covered some of this work. The consideration of the disaggregated analysis of the educational human capital led to refine the allocation of educational resources schemes. This was made possible by integrating directly into the growth equation, PSE related to each level of education to understand the real impact of human capital.

Generally, it is recognized in the literature the positive and significant effect of PSE on economic growth of countries [Barro (1991); Judson (1998); Gupta and Verhoeven (2001); Fernandez and Rogerson (1997); Herrera

\footnotetext{
${ }^{1}$ Gurgand (2000) presents a rich empirical literature on the relationship between human capital and growth. He noted the differences which he advances two hypotheses to explain: one insists on the methodological problems and the other seeks to specify more precisely the role of education based on empirical advances.
} 
(1998); Bose and al (2007)...]. But the effect of PSE by grade level remains to be specified in many countries. Su (2004) analyzes the dynamic effects of the allocation of public funds between basic education and higher. This author uses a dynamic equilibrium model (Lloyd-Ellis, 2000) which explores the involvement of education spending over successive generations of individual and finds that there is low allocations for basic education and the base and higher human capital affects, with opposite signs, global equality and efficiency; results also obtained by Welsch (2008). From an overlapping generation's model, Blankenau and Abington (2013) show that spending on human capital in early childhood generates significant gains for the community. Arcalean and Schiopu (2008) study, for their part, the interaction between public and private spending in a two-stage education framework and their impact on economic growth. They get similar results to previous ones. Bose et al $(2007)^{1}$, distinguishing public investment and total public expenditure on education in their growth equation for many developing countries, show that these two variables have a significant impact on economic growth. All these works attempt to show that, to maximize growth, the share of basic PSE must be high independently of the size of the state budget for an economy in its early stage of development.

Ben Mimoun (2007) and Keller (2006) offer an additional approach that incorporates both level of education and PSE by disintegrated way in the growth equation. Ben Mimoun (2007) attempts, following the pioneering work Gemmell (1995), to organize arbitrage between investments in human capital made to the various school cycles to ensure long-term sustained economic growth for several countries. This author found first that the secondary and higher education positively affects the growth rate in both groups of countries, and that the marginal impact of these forms of human capital is higher in developing countries than in the countries of the OECD. Human capital is formed in the primary, he ruled out the sources of growth stimulation. Second, the marginal returns of PSE are decreasing compared to the level of education in developing countries. It would be optimal to increase public resources more towards the basic cycles in all of those countries. Similarly, he found in its estimates that in countries whose expenditure allocation is biased to the detriment of the lowest grade levels also have low enrollment rates in higher cycles.

Keller (2006) uses several disaggregated measures by level of education (enrollment rates, education spending and education spending per pupil) to understand the impact of education on the GDP growth rate per capita. The sample includes several developed and developing countries for data between 1960 and 2000. The author finds that countries that have increased their enrollment to secondary and higher levels have been rapid growth in the period, as well as those who have spent much more in primary education. The enrollment rate at the primary level has no direct effect on growth but reduces fertility rates, increase physical capital investment and enrollment in secondary school, they impact positive growth. Education spending to lower levels is significant while spending for the higher level is not in the whole sample. The study also shows the influence of education on other development objectives (reducing fertility, attractiveness of physical capital investment, trade openness, lower inflation and recognition of political rights). It appears from this study and the literature review a strong recommendation: to prioritize the allocation of public funds in basic education levels. What about in Cameroon generally absent in the work outlined?

Before answering this question, we note that some literature is rather limited to explanations drastic disparities in the allocation of public education fund by analyzing progressivity ${ }^{2}$ and efficiency ${ }^{3}$ of these expenditures. This is the subject of the next section.

\section{Education cost and efficiency of public spending of education in Cameroon}

This section is divided into two axes. The first examines the per student costs, presents all the factors structuring the variability of these costs and estimate the opportunity cost of schooling in Cameroon. The second area concerns the quantitative and qualitative efficiency of PSE.

To conduct a relevant analysis on the costs of education, it is important first to describe the evolution of students and PSE in the different levels of education (see graphic 1).

\footnotetext{
${ }^{1}$ This study focuses on the relationship between public spending and economic growth in many developing countries. These authors consider public spending several sectors (20).

${ }^{2}$ The analysis of progressivity assesses equity associated with the distribution of PSE.

${ }^{3}$ Efficiency corresponds of a rather general way to the relationship that may exist between the resources deployed and results achieved by the use of these resources. The comparative dimension is important here because it is easier to evaluate whether the education system of one country is more efficient than another as evaluate, in absolute terms, if the efficiency level of a country given at some point of time is high or low.
} 

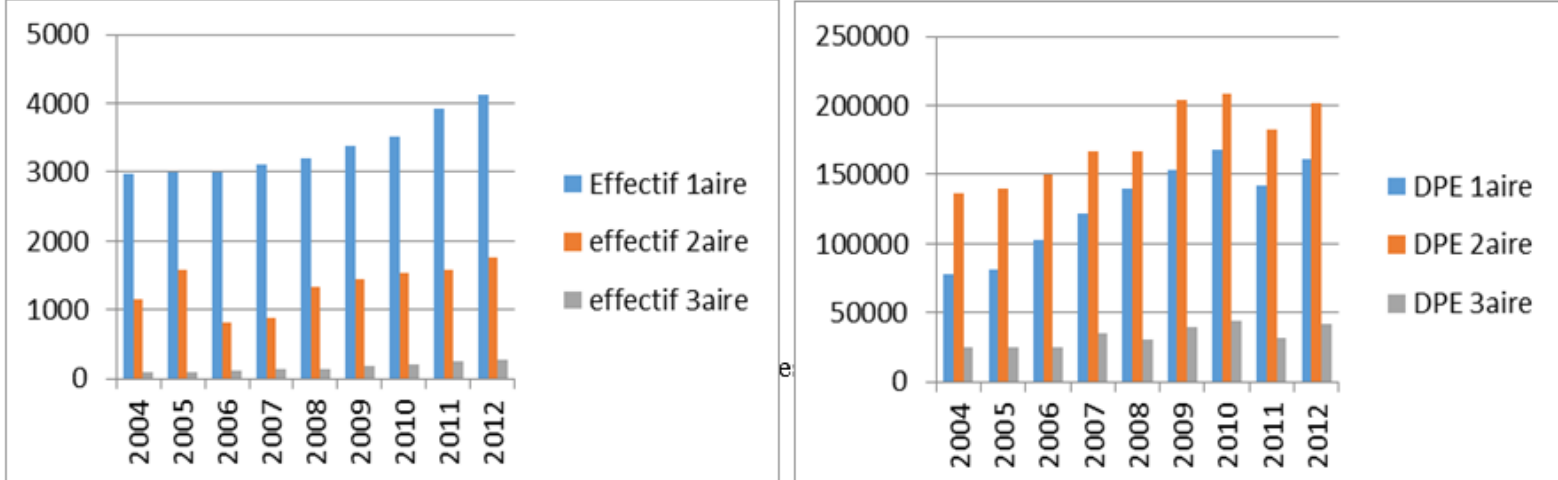

Graphic 1: Distribution of students and PSE by school level in Cameroon between 2004 and 2012

Obviously, we can see from reading the graph that basic education has the largest proportion of the students (more than double in the number of secondary education). While still with low numbers, higher education records a net increase (180\%) between 2004 and 2012. The dynamics of student enrollment is not followed by the evolution of efforts in the education sector. The distribution by level of PSE shows that in relative terms, the secondary school assumes an average half of education spending over the period against $40 \%{ }^{1}$ on average for primary education and $10 \%$ for higher education. Based on the financial volumes mobilized in various levels of education and staff who attend school there, one can directly calculate the current expenditure per student or unit costs of schooling (UCS). The table below shows the estimates obtained in FCFA and in units of GDP per capita of the country during the study period.

On reading the table, we see erratic variations from one year to the other of current expenditure per student. Between 2004 and 2012, the trend is much more bearish on the higher, this relative decline is less in the secondary. By cons, at primary level, unit costs increase progressively during the period. However this level of education possesses the lowest unit costs. For example, consider the year 2010 when the level of education expenditure is highest, the primary UCS is 48,000 FCFA ( $10.3 \%$ of GDP per capita) and represents the third of secondary UCS and fifth of the UCS higher level. This proportional scale has evolved significantly over the period since 2004, the primary UCS was 4.5 times lower than that of secondary and 11 times lower than the higher level. To identify the elements that influence the evolution of these unit costs, it is important to estimate unit costs starting from teaching conditions and resources mobilized on average directly to the student level.

Table 1: Evolution of global unit cost by school in Cameroun between 2004 and 2012

\begin{tabular}{llllllllll}
\hline In FCFA & $\mathbf{2 0 0 4}$ & $\mathbf{2 0 0 5}$ & $\mathbf{2 0 0 6}$ & $\mathbf{2 0 0 7}$ & $\mathbf{2 0 0 8}$ & $\mathbf{2 0 0 9}$ & $\mathbf{2 0 1 0}$ & $\mathbf{2 0 1 1}$ & $\mathbf{2 0 1 2}$ \\
\hline CUS of 1ary & 26210 & 27004 & 34408 & 39080 & 43736 & 45190 & 47786 & 36291 & 39017 \\
\%GDP/hbt & 5.8 & 6 & 7.5 & 8.5 & 9.5 & 9.8 & 10.3 & 7.7 & 8.5 \\
CUS of 2ary & 117071 & 88770 & 184330 & 190542 & 124348 & 141039 & 135032 & 115801 & 114543 \\
\%GDP/hbt & 25.9 & 19.6 & 40.4 & 41.3 & 26.9 & 30.5 & 29 & 24.4 & 24.9 \\
CUS of 3ary & 284884 & 248614 & 205367 & 265076 & 213287 & 225331 & 224159 & 132233 & 149616 \\
\%GDP/hbt & 63 & 55 & 45 & 57.5 & 46.1 & 48.8 & 48.2 & 27.9 & 32.5 \\
CUS global & 56436 & 52629 & 70720 & 78421 & 72008 & 79202 & 80012 & 62194 & 65693 \\
\%GDP/hbt & 12.5 & 11.6 & 15.5 & 17 & 15.6 & 17.2 & 17.2 & 13.1 & 14.3 \\
\hline
\end{tabular}

Source: Calculation of author

The RESEN (2003) for Cameroon recognizes that, whatever the level of education considered, the unit cost (public expenditure per pupil-year) can be expressed as the sum of several components or factors ${ }^{2}$ that main ones are: - wage costs of personnel (especially teachers); - Purchases of everyday goods and services (including pedagogical expenditure); - Aid granted to pupils and students; - And the size of pedagogical groups. With this decomposition, we see that the main component of these costs are related to personnel expenses, which account for $86 \%$ of primary and secondary PSE and is around $50 \%$ in the maternal and higher education. The second component focuses on the pedagogical expenses that are exceptionally superior to personnel expenses in the nursery school (see Table 2). For a complete analysis of unit costs, it is possible to estimate the opportunity costs by level of study (see the calculation methodology in Annex). This would allow having real estimation of the effort made by the government. Like any investment resulting from the choice of rational agents (state or households), education has opportunity costs that guide agents arbitration particularly in the short term, especially in rural areas.

\footnotetext{
${ }^{1}$ Below the outlook for the FIT initiative request to grant $50 \%$ of education in basic education spending to achieve the goal of universal education for all.

${ }^{2}$ These various parameters are combined in the following way to set the level of spending per student in Cameroon: $\mathrm{CU}=\mathrm{SE} / \mathrm{REM}+\mathrm{FONCU}$ + SOCU. Where SE is the average salary of teachers, REM the ratio student per teacher, FONCU operating expenditures per pupil; and SOCU social expenditure average per pupil.
} 
Similarly when recognizes the benefits of education and that it undertakes, arbitrations remain in terms of sector or duration. The opportunity cost of education in Cameroon for the school year 2010 amounts to the sum of 768 billion FCFA. This cost represents the revenue that would have brought the school population in case of renunciation of the studies. Of this amount, must be excluded the corresponding educational expenditure be 148 billion FCFA and obtaining the true value of 620 billion FCFA. This amount is equivalent to $5.5 \%$ of the wealth produced by Cameroon in 2010. By bringing this amount at a student, we determine the opportunity cost of unit amounting to the value of 539523 FCFA in 2010, or $117 \%$ of GDP per capita.

Table 2 : Main components of the unit cost in public schools in 2010

\begin{tabular}{|c|c|c|c|c|c|c|}
\hline \multirow{2}{*}{$\begin{array}{l}\text { In FCFA } \\
\text { (Year 2010) }\end{array}$} & \multicolumn{3}{|c|}{ Staff expenditures } & \multirow[t]{2}{*}{ FONCU } & \multirow[t]{2}{*}{ SOCU } & \multirow[t]{2}{*}{ Total } \\
\hline & Teachers & No-Teachers & Total & & & \\
\hline Pre-primary & 17095 & 6323 & 23418 & 29540 & 0 & 52958 \\
\hline Primary & 29101 & 7736 & 36837 & 5411 & 755 & 43003 \\
\hline General Secondary & 86474 & 25830 & 112304 & 18428 & 617 & 131349 \\
\hline Technical secondary & 152549 & 40551 & 193100 & 30137 & 0 & 223237 \\
\hline Tertiary & 69094 & 52123 & 121217 & 77265 & 25677 & 224159 \\
\hline
\end{tabular}

Source : Calculation of author

The preceding analysis assesses the intensity of the budgetary effort for education by the state. In return of expenditures, educational systems produce results that are different in nature. First, during the schooling, the results can be measured either quantitatively [rates or average lengths of schooling and School Life Expectancy ${ }^{1}$ (SLE)], or qualitatively by the level of learning and knowledge acquired. Bydanova and al (2008) demonstrated that there is a growing relationship between GDP per capita and SLE as well as between PSE and SLE ${ }^{2}$ The quantitative efficiency indicates the number of years of schooling that a country succeeds to provide its people by spending $1 \%$ of its GDP in education. With a percentage of $3.75 \%$ PSE for 2010, we get for Cameroon that one point of GDP allocated to public funding of the education sector generates 2.74 years of schooling. The lack of data for other countries prevents an international comparison to the African level. But in light of data from the year 2004, the situation in Cameroon is better than the average of countries in sub-Saharan Africa (two years). Already for this year, the report for Cameroon amounted to 2.26 years, it can be noted a slight improvement in the quantitative efficiency of PSE. Another way to assess the quantitative efficiency is to analyze the equity of the distribution of educational resources that can be done in two approaches.

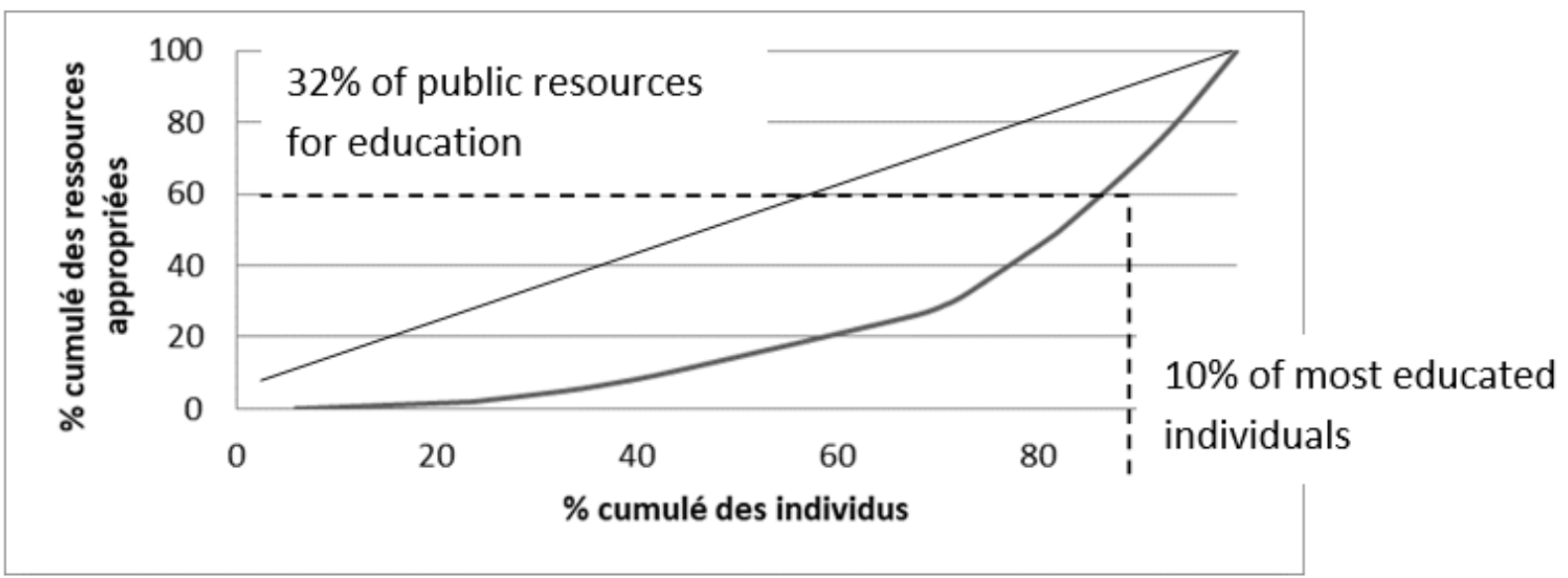

Graphic 2 : Lorenz curve of the distribution of public resources in education, 2010.

The first approach focuses on the structural distribution of public resources within a cohort. With an enrollment profile ${ }^{3}$, we can determine the distribution of terminal levels of schooling in a cohort of young people, as well as define the volume of public resources accumulated to each of these terminals levels of schooling. The results show thus that on a cohort of 100 children, $23 \%$ have as level SIL terminal received only $1.9 \%$ of public education resources; the $68 \%$ who do not go beyond primary school get $26.2 \%$ of public resources; and $11 \%$ who arrive in class Terminal mobilized $80.1 \%$ of public sector resources. In other words, this distribution implies in fact that $10 \%$ of the most educated individuals perceive alone $32 \%$ of PSE (Graphic 2). This reflects a system where PSE are progressive at the level of primary education and regressive in the upper levels.

The second approach takes into account the socioeconomic characteristics of the individuals in the

\footnotetext{
${ }^{1}$ The SLE is located in Cameroon in 2010 to around 9.5 years (UNESCO, 2011). Which is slightly above the average sub-Saharan African countries which SLE is 8.9 years.

${ }^{2}$ Contrary to Altinok (2004), Orivel (1998) and Psacharopoulos and Woodhal (1994) who analyze the efficiency in relation to different TBS and the success rate at the end of primary school, we focus our analysis of the efficiency of the SLE.

${ }^{3}$ The most recent school profile is those of 2003 , is the one that was considered with the 2010 education data.
} 
distribution of PSE. The results obtained after applying the methodology of Demery ${ }^{1}$ show that nearly half of students from three regions of Cameroon namely Central, Western and Littoral appropriated Education Resource evaluated as percentage to $51.8 \%$ (Table 3 ). Hence $48.2 \%$ goes to all of the remaining seven regions. This discrepancy is even more accentuated when making comparisons between regions. The most striking example is between the regions of West and of the Far North. The latter has $15.1 \%$ of enrollment but receives only $11.2 \%$ of resources in education, while the western region, with a lower proportion of enrollments (14.2\%), received more educational resources (16.6\%). These factual findings give a picture of a system in which social inequalities are quite substantial and are growing up with the school level.

Table 3: Geographic disparities in the appropriation of public resources in education

\begin{tabular}{|c|c|c|c|c|c|}
\hline \multirow[t]{2}{*}{ Area $^{2} 2010$} & \multirow{2}{*}{$\begin{array}{l}\text { Distribution } \\
\text { area } \\
\text { Number }\end{array}$} & geographic & \multicolumn{3}{|c|}{$\begin{array}{l}\text { Amount of subsidy education whose } \\
\text { household benefits }\end{array}$} \\
\hline & & $\%$ & Sum (FCFA) & $\%$ & \\
\hline Far-North & 719326 & 15.1 & 20455 & 11.2 & \\
\hline North-West & 489412 & 10.3 & 17946 & 9.9 & \\
\hline North & 408189 & 8.6 & 11081 & 6 & \\
\hline Adamawa & 216323 & 4.6 & 6980 & 3.9 & \\
\hline East & 250998 & 5.3 & 8509 & 4.6 & \\
\hline West & 675165 & 14.2 & 30457 & 16.6 & \\
\hline Sub-west & 332976 & 7 & 15048 & 8.2 & \\
\hline South & 174268 & 3.7 & 8031 & 4.4 & \\
\hline Center & 904577 & 19 & 38716 & 21.2 & \\
\hline Littoral & 577085 & 12.2 & 25595 & 14 & \\
\hline Total & 4787203 & & 182818 & & \\
\hline
\end{tabular}

Source: Author, from data of statistical yearbook 2010 of INS.

The measure of the qualitative efficiency consists in bring together the resources used by the educational system and the level of knowledge ${ }^{3}$ attained by pupils and make comparative analyzes. Compared with PASEC data available, it is clear that Cameroon obtains better results with PSE (3.64\%) lower than the average of the countries considered (4\%). Despite an increase in this expenditure between 1996 and 2005, scores in Mathematics and French decreased during the period (seeTable 4). Although they seem comparatively efficient, it raises the problem of efficiency of these PSE. Now we interested on the analysis of the impact of the distribution of PSE on growth.

Table 4: Scores achieved during the PASEC surveys and public expenditure on education

\begin{tabular}{lllllll}
\hline & \multicolumn{2}{c}{ Score in Mathematic } & \multicolumn{2}{c}{ Score in French } & \multicolumn{2}{c}{ PSE in \% of GDP } \\
\cline { 2 - 7 } Cameroon & PASEC I & PASEC II & PASEC I & PASEC II & $\mathbf{1 9 9 8}$ & $\mathbf{2 0 0 9}$ \\
Ivory Cost & 50 & 46,8 & 55 & 53,4 & 1,93 & 3,64 \\
Madagascar & 58 & 27,3 & 50 & 37,3 & 3,73 & 4,6 \\
Senegal & 38 & 52,6 & 42 & 36,9 & 1,87 & 3,2 \\
Burkina Faso & 46 & 42,1 & 34 & 40,6 & 3,2 & 5,55 \\
Togo & $/$ & 38,5 & 44 & 37,7 & 1,44 & 4 \\
Congo & $/$ & 38,08 & $/$ & 40,76 & 3,98 & 4,11 \\
Chad & $/$ & 36,4 & $/$ & 36,9 & 4,06 & 6,22 \\
Mali & $/$ & 33,9 & $/$ & 31,7 & 1,65 & 3,02 \\
Gabon & $/$ & 35,03 & $/$ & 35,56 & 2,98 & 4,65 \\
Benin & $/$ & 44,3 & $/$ & 61,4 & 3,42 & 4 \\
Burundi & $/$ & 32,5 & $/$ & 31,6 & 2,89 & 4,55 \\
Comores & $/$ & 45 & $/$ & 41,6 & 3,41 & 6,05 \\
\hline Source : A & I & 36,5 & $/$ & 33,6 & 3,78 & 7,6 \\
\hline
\end{tabular}

Source : Author from CONFEMEN reports

\section{Distribution of human capital investment spending and economic growth in Cameroon}

The fundamental assumption that we try to verify empirically states that the inclusion of PSE by disaggregated way allows better understand the influence of education on economic growth. Thus, we will, after Musila and Belassi (2004) for the Ugandan case and Keller (2006) for the general case, develop a model that will incorporate in the growth equation several educational variables and through time Series appreciate the different contributions

\footnotetext{
${ }^{1}$ For a detailed presentation of the methodology refer to the book by Demery (2000) taken by the World Bank in the analysis of education systems in developing countries.

2 This decreasing ranking takes into account the poverty profile by region between 2001 and 2007, report ECAM III.

${ }^{3}$ Cameroon has participated in the PASEC tests knowledge acquisition in 1996 and 2005. It is possible to see if the change in the quality of education follows the variation of PSE.
} 
of each of the estimated variables.

\subsection{Operational framework}

The basic equation of our model is the result of developments in the model of Mankiw, Romer and Weil (1992) and is as follows: $g_{t}=\alpha+\beta \ln y_{t}+\gamma_{i} X_{t}+v_{t}$

The annual growth rate of GDP per capita $\boldsymbol{g}_{\boldsymbol{t}}$ is the main variable to be explained. $\boldsymbol{l n} \boldsymbol{y}_{t}$ is the natural logarithm of GDP per capita; $\boldsymbol{X}_{\boldsymbol{t}}$ is the vector of all other explanatory variables considered.

In the vector of the explanatory variables $X$, there is a sub vector Edu with educational variables. It was first the gross enrollment rate by level of education noted $\mathbf{e}_{\mathrm{i}}(\mathrm{i}=1,2$ and 3$)$. Then we have the report on GDP of PSE noted $\mathbf{p}_{\mathrm{i}}(\mathrm{i}=1,2$ and 3$)$. Then we also take into account the share of the unit cost of education (educational expenditure per student) on GDP per capita represented by $\mathbf{s}_{\mathbf{i}}$, for primary, secondary and tertiary level. Finally, we will integrate with the variables related to education, a Gini index of human capital distribution in each level of education that we note $\mathbf{I G E}^{\mathbf{1}}$ and $\mathbf{I G D}^{\mathbf{2}}$ and $\mathbf{I G C}^{\mathbf{3}}$. The rest of the control variables are: the rate of investment in physical capital (I); the degree of trade openness, Trade, which is the ratio between the sum of exports and imports on GDP; the fertility rate (f); non-educational public spending (NDPE); and finally the growth rate of the consumer price index (Infl). In detail, the equation (1) is as follows in three forms by considering three specific educational measures adopted:

$g_{t}=\alpha_{t}+\beta_{1} e_{1 t}+\beta_{2} e_{2 t}+\beta_{3} e_{3 t}+\beta_{4} I G E_{t}+\gamma_{j} X_{t}+v_{t}$

$g_{t}=\alpha_{t}+\beta_{1} p_{1 t}+\beta_{2} p_{2 t}+\beta_{3} p_{3 t}+\beta_{4} I G D_{t}+\gamma_{j} X_{t}+v_{t}$

$g_{t}=\alpha_{t}+\beta_{1} s_{1 t}+\beta_{2} s_{2 t}+\beta_{3} s_{3 t}+\beta_{4} I G C_{t}+\gamma_{j} X_{t}+v_{t}$

Avec: $\gamma_{j} X_{t}=\gamma_{0} \operatorname{lny}_{t}+\gamma_{1} I_{t}+\gamma_{2}$ Trade $_{t}+\gamma_{3}$ Infl $l_{t}+\gamma_{4} N D P E_{t}$.

Table 5: Descriptive statistics of variables

\begin{tabular}{llllll}
\hline & Observations & Means & St. dev. & Min. & Max. \\
\hline g & 31 & -0.1846441 & 4.112743 & -10.51159 & 4.972558 \\
e1 & 31 & 98.78729 & 12.59293 & 75.84776 & 120 \\
e2 & 31 & 29.53031 & 9.856515 & 17.77539 & 58.8 \\
e3 & 31 & 4.522934 & 2.836898 & 1.57658 & 12.446 \\
p1 & 31 & 9.097742 & 2.903941 & 4.64 & 15.13 \\
p2 & 31 & 12.18 & 3.740887 & 6.18 & 19.57 \\
p3 & 31 & 3.140968 & 1.125668 & 1.04 & 5.13 \\
s1 & 31 & 5.812903 & 1.908532 & 3.1 & 10.3 \\
s2 & 31 & 27.46129 & 6.127081 & 15.5 & 41.3 \\
s3 & 31 & 83.40968 & 30.9052 & 27.9 & 138.5 \\
IGD & 31 & 0.8010323 & 0.139114 & 0.404 & 0.999 \\
IGE & 31 & 0.50634 & 0.0729323 & 0.42275 & 0.64924 \\
IGC & 31 & 0.813229 & 0.1217148 & 0.5567 & 0.95 \\
\hline
\end{tabular}

The objective of the article is to assess the effect of the distribution of PSE on economic growth, and we will interest only on the educational variables. Using the sub-vector Edu $\left(\mathbf{e}_{\mathbf{i}}, \mathbf{p}_{\mathrm{i}}\right.$, and $\left.\mathbf{s}_{\mathbf{i}}\right)$ we will test the contribution of education to growth in Cameroon with an interest in the distributive aspects. The expected sign is positive for these three indicators. Variables IGD, IGC and IGE, introduced in equations (2), (3) and (4) relates to the distribution of education and PSE between school cycles and would have a predicted negative sign because the results of Ben Mimoun (2007) lead to the conclusion that countries with allocations of PSE are biased to the detriment of basic school cycles have low growth rates.

Data on gross enrollment ratio are from the UNESCO database. Regarding PSE, we use the laws of finances and economic and financial reports of Cameroon (1982-2012). Data on other indicators and GDP per capita are provided by the recent World Bank database, WDI (World Development Indicators) of 2013. The summary statistics of all variables are presented in Table 5.

\subsection{Estimations results and analysis}

The analysis of the stationary of our series is a prerequisite for our econometric study. Unit root test Phillips-Perron

${ }^{1}$ Vinod and al (2000) specified IGE following the formula:

${ }^{2}$ Following Ben Mimoun (2007) the formula of IGD is :

$$
I G E=\frac{1}{\mu} \sum_{i=2}^{n} \sum_{j=1}^{i-1} p_{i}\left|y_{i}-y_{j}\right| p_{j}
$$

$$
I G D=\frac{1}{\overline{D P E}}\left[\left(l_{p}-l_{s}\right)\left|D_{p}-D_{s}\right|+\left(l_{p}-l_{t}\right)\left|D_{p}-D_{t}\right|+\left(l_{s}-l_{t}\right)\left|D_{s}-D_{t}\right|\right.
$$

Where: $\overline{D P E}$ is PSE average; $l_{i}$ is the enrolments rate at level $\mathrm{i}$; and $D_{i}$ is PSE at the level $\mathrm{i}$.

${ }^{3}$ IGC is the equivalent of the IGD in terms of unit cost of schooling. 
(1988) was used to determine the stationary or not to our different series. This test reveals that our series are integrated of order 1, because the first difference of each of these variables is stationary (Table 6). The Trace test of Johansen leads to detect the number of co-integrating vectors. We note after application of the test, there are two relationships co-integration between the variables in equation (2) and (4). For equation (3), a single cointegration relationship was detected (Table 7). We will request in this case the model VECM for estimation.

Table 6 : Characteristics of times series

\begin{tabular}{llll}
\hline Variables & PP Statistique in level & PP Statistique in first difference & Intégration order \\
\hline $\mathrm{g}$ & $-7.82(-18.28)^{*}$ & $-27.480(-18.204)^{*}$ & $\mathrm{I}(1)$ \\
$\mathrm{e} 1$ & 0.178 & -25.079 & $\mathrm{I}(1)$ \\
e2 & 0.883 & -21.330 & $\mathrm{I}(1)$ \\
e3 & 2.937 & -8.057 & $\mathrm{I}(1)$ \\
p1 & 0.698 & -28.973 & $\mathrm{I}(1)$ \\
p2 & 0.612 & -30.278 & $\mathrm{I}(1)$ \\
p3 & 0.525 & -41.553 & $\mathrm{I}(1)$ \\
s1 & 0.468 & -28.232 & $\mathrm{I}(1)$ \\
s2 & -0.603 & -25.857 & $\mathrm{I}(1)$ \\
s3 & -1.052 & -30.602 & $\mathrm{I}(1)$ \\
IGD & -0.479 & -26.433 & $\mathrm{I}(1)$ \\
IGC & -0.466 & -33.833 & $\mathrm{I}(1)$ \\
IGE & -0.42 & -32.377 & $\mathrm{I}(1)$ \\
\hline
\end{tabular}

*Critical values of PP statistic at $5 \%$ for the dependant variable $\mathrm{g}$. For others variables the critical values are similar. We have in level $\mathrm{PP}=-7.38$ and in first difference $\mathrm{PP}=-7.364$.

Table 7: Results of Johansen test of co-integration for each equation of model

\begin{tabular}{lllll}
\hline & Eigen-value & Trace statistique & Critical value (5\%) & Integration number \\
\hline Equation (2) & 0.63479 & 23.3855 & 29.68 & 2 \\
Equation (3) & 0.68685 & 54.016 & 54.64 & 1 \\
Equation (4) & 0.59959 & 28.226 & 29.68 & 2 \\
\hline
\end{tabular}

The economic literature suggests that inequality affects economic growth. What about inequality of Education (IGE) and distribution of PSE (IGD and IGC). To determine the endogenous variable in our long-term relationships, we performed Granger causality test. The completion of this test shows that these inequalities Granger influence economic growth and vice versa except IGD where growth has no influence on this inequality (Table 9). The correlation matrix suggests the direction of the expected correlation between variables. A reading of Table 8 , we see that inequality and economic growth are negatively correlated.

Table 8 : Correlation Matrix of different variables

\begin{tabular}{|c|c|c|c|c|c|c|c|c|c|c|c|c|c|}
\hline & $\mathrm{g}$ & e1 & e2 & e3 & $\mathrm{p} 1$ & p2 & p3 & s1 & s2 & s3 & IGE & IGD & IGC \\
\hline g & 1 & & & & & & & & & & & & \\
\hline e1 & 0.07 & 1 & & & & & & & & & & & \\
\hline e2 & 0.04 & 0.7 & 1 & & & & & & & & & & \\
\hline e3 & 0.16 & 0.74 & 0.78 & 1 & & & & & & & & & \\
\hline p1 & -0.06 & 0.83 & 0.67 & 0.83 & 1 & & & & & & & & \\
\hline p2 & -0.06 & 0.86 & 0.68 & 0.81 & 0.97 & 1 & & & & & & & \\
\hline p3 & -0.14 & 0.34 & 0.58 & 0.66 & 0.67 & 0.67 & 1 & & & & & & \\
\hline s1 & -0.02 & 0.74 & 0.59 & 0.82 & 0.96 & 0.93 & 0.71 & 1 & & & & & \\
\hline s2 & -0.12 & 0.38 & -0.21 & 0.04 & 0.42 & 0.42 & -0.05 & 0.38 & 1 & & & & \\
\hline s3 & -0.35 & -0.77 & -0.62 & -0.79 & -0.7 & -0.72 & -0.25 & -0.68 & -0.19 & 1 & & & \\
\hline IGE & -0.12 & -0.44 & -0.68 & -0.78 & -0.63 & -0.65 & -0.82 & -0.65 & 0.19 & 0.57 & 1 & & \\
\hline IGD & -0.03 & 0.28 & -0.24 & -0.25 & 0.02 & 0.05 & -0.65 & -0.08 & 0.62 & -0.17 & 0.54 & 1 & \\
\hline IGC & -0.13 & -0.78 & -0.77 & -0.92 & -0.85 & -0.83 & -0.57 & -0.88 & -0.03 & 0.83 & 0.69 & 0.13 & 1 \\
\hline
\end{tabular}

Table 9 : Results of Granger causality test between growth and distribution of PSE

\begin{tabular}{llll}
\hline Null hypothesis & Chi2 & df & Prob>chi2 \\
\hline IGE does not Granger cause g & 1.7459 & 2 & 0.418 \\
\hline g does not Granger cause IGE & 4.5666 & 2 & 0.102 \\
IGD does not Granger cause g & 3.1492 & 2 & 0.207 \\
g does not Granger cause IGD & 6.954 & 2 & 0.031 \\
IGC does not Granger cause g & 0.1254 & 2 & 0.939 \\
g does not Granger cause IGC & 3.1583 & 2 & 0.206 \\
\hline
\end{tabular}


To see if our equations are co-integration relations, we apply the Phillips-Perron test to residues of the estimates of long-term relationship. The Phillips-Perron statistics are lower than the estimated critical values to $5 \%$, this allows us to reject the hypothesis of non-stationary residuals. Therefore, all variables are co-integrated, we can say that our relations specified are co-integration relationships. The exogenous test which is carried through the adjustment coefficient (TCE in the table 11) associated with the co-integration vectors indicates the convergence of the trajectories of the growth rate series or level of inequalities to long-term target. This test validates the error correction representation in equation (2) when the dependent variable is growth. In equation (3), every two specifications are validated. And in equation (4), the validation is obtained with as the dependent variable inequality. We also find that the adjustment parameters associated with the explanatory variables are not significant, so these variables are weakly exogenous. This non-significance of the other variables allows us to affirm that there is no short-term relationship between the GDP growth rate per capita, educational variables and distribution of PSE (Table 11).

Significantly, the results of co-integration model (Table 10) show that the distribution of Education (IGE) and UCS (IGC) between levels of education has a negative effect on economic growth in Cameroon. In other words, the decline of these inequalities promoted growth. By cons, regarding the distribution of PSE (IGD), the effect is positive on growth. The small decrease of this inequality, whose level is still high in 2012 (0.719), causes negative growth rate. This clearly calls for a reorganization of budgetary allocations in the education sector in favor of basic education.

Table 10: The estimation results of the various co-integration models

\begin{tabular}{|c|c|c|c|}
\hline $\begin{array}{l}\text { Dependant Variable } \\
(\mathrm{g})\end{array}$ & $\begin{array}{c}\text { Equation (2) } \\
\text { (z-stat) }\end{array}$ & $\begin{array}{c}\text { Equation (3) } \\
\text { (z-stat) }\end{array}$ & $\begin{array}{c}\text { Equation (4) } \\
\text { (z-stat) }\end{array}$ \\
\hline $\mathrm{E}_{1}$ & $\begin{array}{l}-0.00555^{*} \\
(1.87)\end{array}$ & $\begin{array}{l}4.2292 * * * \\
(3.07)\end{array}$ & $\begin{array}{l}-0.00888^{* *} \\
(-2.31)\end{array}$ \\
\hline $\mathrm{E}_{2}$ & $\begin{array}{l}0.3584 \\
(1.10)\end{array}$ & $\begin{array}{l}-8.1285 * * * \\
(-5.98)\end{array}$ & $\begin{array}{l}0.4322 * * * \\
(2.79)\end{array}$ \\
\hline $\mathrm{E}_{3}$ & $\begin{array}{l}0.1191 \\
(0.06)\end{array}$ & $\begin{array}{l}25.6001 * * * \\
(6.14)\end{array}$ & $\begin{array}{l}0.3458 * * * \\
(7.05)\end{array}$ \\
\hline $\mathrm{IG}_{\mathrm{i}}$ & $\begin{array}{l}-155.49 * * * \\
(-3.36)\end{array}$ & $\begin{array}{l}161.409 * * * \\
(6.52)\end{array}$ & $\begin{array}{l}-60.8361 * * * \\
(-4.98)\end{array}$ \\
\hline
\end{tabular}

Source : Estimation results under Stata

Table 11: Results of the estimation of the vector error correction model

\begin{tabular}{|c|c|c|c|c|c|c|}
\hline \multirow{2}{*}{$\begin{array}{l}\text { Dependant } \\
\text { Variable }\end{array}$} & \multicolumn{2}{|c|}{ Equation (2) } & \multicolumn{2}{|c|}{ Equation (3) } & \multicolumn{2}{|c|}{ Equation (4) } \\
\hline & $\begin{array}{l}\Delta \mathrm{g} \\
\text { (z-stat) }\end{array}$ & $\begin{array}{l}\Delta \text { IGE } \\
\text { (z-stat) }\end{array}$ & $\begin{array}{l}\Delta \mathrm{g} \\
\text { (z-stat) }\end{array}$ & $\begin{array}{l}\Delta I G D \\
\text { (z-stat) }\end{array}$ & $\begin{array}{l}\Delta \mathrm{g} \\
\text { (z-stat) }\end{array}$ & $\begin{array}{l}\mathrm{\Delta IGC} \\
\text { (z-stat) }\end{array}$ \\
\hline TCE & $\begin{array}{l}-0.0404 \\
(-0.65)\end{array}$ & $\begin{array}{l}0.0007 * * * \\
(4.57)\end{array}$ & $\begin{array}{l}-0.0134 \\
(-0.11)\end{array}$ & $\begin{array}{l}-0.0047 \\
(-1.49)\end{array}$ & $\begin{array}{l}0.1893 \\
(1.39)\end{array}$ & $\begin{array}{l}-0.0017 \\
(-0.64)\end{array}$ \\
\hline$\Delta \mathrm{g}(-1)$ & $\begin{array}{l}0.154 \\
(0.59)\end{array}$ & $\begin{array}{l}-0.0015^{* *} \\
(-2.31)\end{array}$ & $\begin{array}{l}0.0348 \\
(0.13)\end{array}$ & $\begin{array}{l}0.0032 \\
(0.47)\end{array}$ & $\begin{array}{l}-0.1904 \\
(-0.72)\end{array}$ & $\begin{array}{l}0.001 \\
(0.20)\end{array}$ \\
\hline$\Delta \mathrm{E}_{1}(-1)$ & $\begin{array}{l}-0.0068 \\
(-0.04)\end{array}$ & $\begin{array}{l}-0.0005 \\
(-1.30)\end{array}$ & $\begin{array}{l}-0.0448 \\
(-0.05)\end{array}$ & $\begin{array}{l}0.0082 \\
(0.38)\end{array}$ & $\begin{array}{l}-0.1915 \\
(-0.08)\end{array}$ & $\begin{array}{l}0.0585 \\
(1.19)\end{array}$ \\
\hline$\Delta \mathrm{E}_{2}(-1)$ & $\begin{array}{l}-0.0903 \\
(-0.77)\end{array}$ & $\begin{array}{l}0.00014 \\
(0.49)\end{array}$ & $\begin{array}{l}0.09 \\
(0.10)\end{array}$ & $\begin{array}{l}0.0358 \\
(1.47)\end{array}$ & $\begin{array}{l}-0.0569 \\
(-0.14)\end{array}$ & $\begin{array}{l}-0.0057 \\
(-0.75)\end{array}$ \\
\hline$\Delta \mathrm{E}_{3}(-1)$ & $\begin{array}{l}-0.1108 \\
(-0.07)\end{array}$ & $\begin{array}{l}-0.0042 \\
(-1.12)\end{array}$ & $\begin{array}{l}-0.1213 \\
(-0.06)\end{array}$ & $\begin{array}{l}-0.0818 \\
(-1.44)\end{array}$ & $\begin{array}{l}-0.0593 \\
(-1.00)\end{array}$ & $\begin{array}{l}-0.0003 \\
(-0.28)\end{array}$ \\
\hline$\Delta \mathrm{IG}_{\mathrm{i}}(-1)$ & $\begin{array}{l}66.183 \\
(1.14)\end{array}$ & $\begin{array}{l}-0.737 * * * \\
(-5.01)\end{array}$ & $\begin{array}{l}-5.9247 \\
(-0.43)\end{array}$ & $\begin{array}{l}-0.6367 * \\
(-1.87)\end{array}$ & $\begin{array}{l}5.3557 \\
(0.12)\end{array}$ & $\begin{array}{l}0.6671 \\
(0.77)\end{array}$ \\
\hline
\end{tabular}

Source : Estimation results under Stata

The results of the estimation of co-integration model of equation (2) with the enrollment rate show that this latter has differentiated impacts on growth in Cameroon. The primary school enrollment rate acts to the detriment of growth while those of secondary and tertiary act positively on economic growth. These positive effects are not significant. The unexpected effect observed at the primary level may be due to the low quality of education. Considering PSE (\% of GDP) as educational variables in the equation (3), we obtain substantially results opposite to previous. PSE in primary and tertiary positively affect economic growth in Cameroon and negatively for secondary PSE. These results are contrary to those of Keller (2006) that found only a positive impact for PSE at the primary level in developing countries. The last variable is the educational enrollment unit cost (UCS) integrated into the equation (4). The estimation results show that UCS in primary has a negative impact and UCS in secondary and higher have positive effects on the growth rate in Cameroon. All these effects are very significant. Once more, 
this result is contrary to those of Keller (2006) which rather demonstrates the positive impact of UCS primary. Contrary to other educational variables, increased of UCS primary allows finding a positive and significant impact of education spending per capita of basic education head on the growth rate.

These results led to take position for reallocation of educational resources to support basic education. With large educated enrolments in primary education and school life expectancy hovering around 10 years, it appears necessary to allocate more PSE at the primary level and increase or maintain PSE in secondary education to accommodate students who succeed at primary level. Aghion and Cohen (2004) defend the hierarchical nature of any education system. Indeed, for them for efficient investment in graduate students, it is necessary to have solid investments in elementary cycles and it is essential for individuals to successfully complete the lower school cycles. The proposed budget reallocation would ensure better internal redistribution within the education system and also compensate the inequality of household incomes. As a whole and for each cycle, the educational public service is less unequally distributed among socio-professional category as household incomes. This trend is much shared in many developed countries where the interest of introducing this aspect in developing countries where the situation is quite opposite.

\section{Conclusion}

In the case of Cameroon, the education sector is characterized by an unequal distribution of educational resources. Primary education with $70 \%$ of enrollments in 2010 received only $40 \%$ of spending on education against $50 \%$ for secondary that has $26 \%$ of enrollments and $10 \%$ for higher education has $4 \%$ of enrollments (trend observed since 2005). Additionally, spending per capita is 43826 FCFA for basic education, against 148,875 FCFA for secondary education and 224477 FCFA for higher education. Governments spend nearly 3.5 and 5 times respectively for children of secondary and higher education than at primary level. Calculating an opportunity cost evaluates the "loss" to 5.5\% of the wealth produced on Cameroon during the 2010 school year. By bringing this amount at a student, the opportunity cost per unit is determined amounting to the value of 539,523 FCFA or $117 \%$ of GDP per capita. Although, comparatively, PSE are qualitatively and quantitatively efficient, we estimated by the VECM model, the effect of their distribution by level of education on the growth rate of the economy of Cameroon. We find that there is no short-term relationship between the GDP growth rate per capita, educational variables and distribution of PSE. The results of the estimation of co-integration relationships showed differential effects of this distribution on economic growth. The distribution of Education (IGE) and unit costs of schooling (IGC) between levels of education has a negative effect on Cameroon's economic growth. By cons, regarding the distribution of PSE (IGD), the effect is positive on growth. The small decrease of this inequality, whose level is still high in 2012 (0.719), causes negative growth rate. While the enrollment and UCS primary negatively affect growth, we find that the PSE in the upper levels have positive effects. So, our results argue for a profound readjustment of the PSE breakdown structure in Cameroon. It is essential to allocate more public resources for basic education and maintenance of PSE level in secondary education.

\section{References}

Abington, C. and W. Blankenau (2013), "Government education expenditures in early and late childhood", Journal of Economic Dynamics and Control 37(4), 854-874.

Aghion P. and É. Cohen (2004), Éducation et croissance: rapport, Paris : la Documentation française.

Arcalean, C. and I. Schiopu (2010), "Public versus private investment and growth in a hierarchical education system", Journal of Economic Dynamics and Control 34(4), 604-622.

Barro, R. (1991), "Economic growth in a cross section of countries", Quarterly Journal of Economics 106, 407444.

Ben Mimoun (2007), Dépenses publiques d'éducation et performances économiques, Thèse de doctorat, Paris, France, Université Panthéon-Sorbonne.

Bose, N., M. E. Haque and D. R. Osborn (2007), "Public Expenditure and Economic Growth: A Disaggregated Analysis for Developing Countries", The Manchester School 75(5), 533-556.

Bydanova, E., A. Mingat and B. Suchaut (2008), “Qualité et efficience de l'école primaire française : éléments de comparaisons spatiales et temporelles", Document de travail, IREDU.

Driskill, R.A. and A. W. Horowitz (2002), "Investment in Hierarchical Human Capital", Review of Development Economics 6(1), 48-58.

Fernández, R. and R. Rogerson (1999), “Education finance reform and investment in human capital: lessons from California", Journal of Public Economics 74(3), 327-350.

Fuente, D. and R. Doménech (2006), "Human Capital in Growth Regressions: How Much Difference Does Data Quality Make?", Journal of the European Economic Association 4(1), 1-36.

Galor, O. and D. Tsiddon (1997), "The Distribution of Human Capital and Economic Growth", Journal of Economic Growth 2(1), 93-124.

Gemmell, N. (1995), “Endogenous growth, the Solow model and human capital”, Economics of Planning 28(2- 


\section{3), 169-183.}

Glomm, G. and B. Ravikumar (2001), "Human capital accumulation and endogenous public expenditures", Canadian Journal of Economics 34(3), 807-826.

Gupta, S. and M. Verhoeven (2001), "The efficiency of government expenditure: experiences from Africa", Journal of Policy Modeling 23(4), 433-467.

Gurgand, M. (2000), "Capital humain et croissance: la littérature empirique à un tournant", Économie publique/Public economics 6.

Herrera, R. (1998), "Dépenses publiques d'éducation et capital humain dans un modèle convexe de croissance endogène", Revue économique 49(3), 831-844.

Judson, R. (1998), "Economic Growth and Investment in Education: How Allocation Matters", Journal of Economic Growth 3(4), 337-359.

Keller (2006), "Investment in Primary, Secondary, and Higher Education and the Effects on Economic Growth", Contemporary Economic Policy 24(1), 18-34.

Khalifa Al-Yousif (2005), "Education expenditure and economic growth: some empirical evidence from the gcc countries", Working Paper, Project MUSE.

Krueger, A.B. and Lindahl M. (2001), "Education for Growth: Why and for Whom?”, Journal of Economic Literature 39(4), 1101-1136.

Lloyd-Ellis, H. (2000), "Public Education, Occupational Choice, and the Growth-Inequality Relationship", International Economic Review 41(1), 171-202.

Mankiw, N.G., Romer D. and Weil D.N. (1990), "A Contribution to the Empirics of Economic Growth", Working Paper, $n^{\circ} 3541$, National Bureau of Economic Research.

Mingat, A. and Suchaut B. (2000), Les systèmes éducatifs africains: une analyse économique comparative, Bruxelles : De Boeck Supérieur.

Mingat A. and Tan J.-P. (1998), The Mechanics of Progress in Education: Evidence from Cross-country Data, Washington: World Bank Publications.

Musila, J. and Belassi W. (2004), "The Impact of Education Expenditure on Economic Growth in Uganda: Evidence from Time Series Data,” The Journal of Developing Area 38(1), 123-133.

Psacharopoulos, G. and Patrinos H.A (1994), "Returns to investment in education: A global update", World Development 22(9), 1325-1343.

Rapport d'Etat sur le Système Educatif National (2003) Cameroun, Banque Mondiale.

$\mathrm{Su}, \mathrm{X}$. (2004), "The allocation of public funds in a hierarchical educational system", Journal of Economic Dynamics and Control 28(12), 2485-2510.

Tamang, P. (2011), "The Impact of Education Expenditure on India's Economic Growth", Journal of International Academic Research 11(3), 14-20.

Welsch, D. M. (2008), “Government Expenditures on Primary, Secondary, and Tertiary Education”, The Journal of Developing Areas 42(2), 129-156.

Yahya, M. and Razack A. (2012), "Education Expenditure and Economic Growth: A Causal Analysis for Malaysia", Journal of Economics and Sustainable Development 3(7).

\section{APPENDIX \\ Methodology of calculation of opportunity cost}

For the analysis of school opportunity costs, an approach by the occupation time seems useful for households and yields approach is essential for the community. The chosen approximation assumes that the opportunity cost of investment in education can be measured by the labor income that would have been individuals without schooling. According to Psacharopoulos (1994), this approximation leads to underestimate the returns of the primary education given the fact that age children attend primary school are not, or at least not all, working age. Although suffering from a lack of available data and are not representative of the general population, this approach was popularized by several specialists. And the opportunity costs of the state by level will be calculated based on the age of the school-age population. The INS holds for Cameroon, the age of 4-11 years for primary, secondary 1218 years (including 12-15 years for the first cycle and 16-18 years for 2nd cycle) and $19-24$ years for higher education. We distinguish for calculating this cost, the population aged 4-15 years whose income of the occupancy time will be considered invalid on the one hand and the population aged 16-24 years whose potential wage income rather taken account. Indeed, ECAM3 gives us an occupancy rate of the active population and the distribution of assets occupied by institutional sector. For monetary characteristics of different assets occupied, one must refer to the reports of recent surveys EESI. The statistics obtained will be applied to the various staff of the school population (15-24 years) to calculate the different opportunity costs for the study period. Considering the 2010 Statistical Yearbook of data that gives us the number of students by age and taking into account the activity rate of the age group 15-29 years (72\%), we get all the various elements necessary for calculating the opportunity cost. 